\title{
Logopedics management in neurovascular diseases
}

\author{
R Mazzeo
}

From de Senectute: Age and Health Forum

Catanzaro, Italy. 5-7 December 2009

The Neurovascular diseases acquired are of great social impact, they are the second cause of death in the world and the most frequent cause of disability in adults.

The role of speech therapy in the management of this long process of care is crucial. He must manage the rehabilitation and / or the rearrangement of several functions, as well as social problems related to families, work and school.

The patient with severe brain injury in addition to the symptom of aphasia which is the most evident of different origin etiology pathogenesis, will, in addition to symptoms of expression of cortical impairments responsible for other functions, including other brain impairments of other body structures in subjects treated with certain medications, in a social and emotional detail and with a history of the all subjective.

In all this, what is most important for the speech therapist is taking charge of cerebrovascular patients to be made following the evidence based on experience that can contribute to a core-competence.

Published: 19 May 2010

- Convenient online submission

- Thorough peer review

- No space constraints or color figure charges

- Immediate publication on acceptance

- Inclusion in PubMed, CAS, Scopus and Google Scholar

- Research which is freely available for redistribution 